\title{
Banking the Unbanked: A Mechanism for Improving the Financial Security of Low-Income Individuals
}

\author{
By Emily Robbins
}

Expanding access to financial literacy and to low-cost banking services are important policy issues that may help prevent some of the financial pitfalls that disproportionately affect low-income individuals. This paper explains the causes and effects of being "unbanked" (i.e. not using the traditional banking system), and explains why it is important to bring everyone into the financial mainstream. In addition, this paper highlights the structure and implementation of a successful public-private partnership program called Bank On San Francisco that provided financial literacy courses and low-cost checking accounts to at-risk residents in San Francisco. Lastly, this paper discusses several important economic considerations for policymakers to analyze before replicating the Bank On San Francisco program in other jurisdictions, and also reviews federal action on financial literacy and banking the unbanked.

\section{Introduction}

For many low-income individuals who are living paycheck to paycheck, opening a checking account is a first step toward a stronger financial future. Using a mainstream checking account is a conduit for accumulating savings, maintaining good credit, and earning assets, all of which are critical building blocks for helping individuals with limited disposable income create financial stability. However, transaction costs (such as minimum required balances or monthly fees) and a lack of financial literacy regarding the high cost of alternative banking services are barriers to conducting business with traditional financial institutions (National League of Cities 2011).

Instead, many low-income households rely on expensive non-bank financial institutions such as check cashers and payday lenders. That is because these alternatives are geographically accessible, and many consumers are uninformed about their high costs (Fellowes and Mabanta 2008). Check cashers cash checks for a fee, and do not require that customers have a checking account. Payday lenders provide short-term loans at high interest rates. Neither check cashers nor payday lenders are considered part of the traditional banking industry (Fellowes and Mabanta), and they also operate independently from federal regulation and oversight (Cordray 2012). Check-cashers are regulated at the state level; however, 15 states do not regulate them at all (Fellowes and Mabanta).

A person who does not have a traditional bank account and uses alternative financial services is defined as "unbanked" (Pew Health Group 2011, 2). The banking habits of the unbanked can perpetuate the need to live paycheck to paycheck because alternative banking services can actually be more expensive to use in the long term (Fellowes and Mabanta 2008). 
The policy area known as "banking the unbanked" introduces low-income, unbanked individuals to traditional banking services so they can benefit from a system that may enable them to retain more of their income and, as a result, strengthen their financial security and improve their socioeconomic status.

This paper discusses the benefits of banking the unbanked, explains the barriers that low-income populations face in using the traditional banking industry, and describes a program named Bank On San Francisco which effectively banked about 20 percent of the city's unbanked population in one year and whose success motivated public officials in other major US cities such as Seattle, Houston, and Washington, DC to adopt similar "Bank On” programs (Phillips and Stuhldreher 2011). This paper also reviews important economic considerations for policymakers to examine before implementing a Bank On model program in their city or county, and highlights the social value in bringing more low-income individuals into the mainstream banking market.

\section{Banking the Unbanked: Why It Is Necessary}

Banking the unbanked encourages the utilization of a banking industry that provides consumers with access to more of their income and expands financial literacy (or financial "know-how") around the issues of banking and lending (Phillips and Stuhldreher 2011).

One of the most important reasons to bank the unbanked is that services cost less at traditional banks, which means consumers can save money in the long term by using banks versus check cashers and payday lenders. According to the Brookings Institution, an individual pays an average of $\$ 40$ in fees to cash a paycheck via a check-cashing service. However, these fees can be avoided by opening a low-cost checking account at a traditional bank, which generally cash checks for free (Fellowes and Mabanta 2008). In fact, a worker could potentially spend over $\$ 41,000$ during his or her career on check casher fees (Fellowes and Mabanta 2008). In addition, the high-cost payday lending market charges interest rates at an average of 25 to 30 times higher than traditional banks (Fellowes and Mabanta 2008) and the continuous use of payday lenders can cause low-income individuals to accumulate a large amount of debt.

Using a bank account also ensures that a person's money is stored in a secure place and is safeguarded against house fires, burglary, and other circumstances wherein physical bills and coins could be stolen or ruined. In her analysis of issues facing the unbanked, Yale professor and economist Ebonya Washington asserts that using traditional bank accounts helps individuals hold on to their cash because "money held in a bank may be less likely to be stolen, spent on impulse, or given to friends and family. [Alternative] banks do not compete with traditional banks in providing a haven for savings" (Washington 2006, 109).

Individuals who are unbanked do not have the opportunity to build a credit history and earn a good credit score, which are critical factors in qualifying for a car loan, home mortgage, or a loan for higher education. According to the Consumer Financial Protection Bureau (CFPB), a credit score is an indicator of an individual's likelihood to pay back a loan based on his or her history of paying credit card bills on time (CFPB 2013b). Unbanked individuals do not have credit cards or bank accounts, and therefore cannot build a credit history or earn a good credit score (Desmond and Sprenger 2007).

Having no credit history may actually motivate low-income individuals to use payday lenders in the first place. A Federal Reserve Bank of Boston report explains that "unbanked individuals frequently lack sufficient credit histories to satisfy the requirements of traditional lenders and are often obliged to resort to high-interest, informal loan products. 
These expensive loans can easily balloon out of control, at times becoming more costly than their initial value" (Desmond and Sprenger 2007, 26). Banking the unbanked helps provide access to more than just the opportunity to save money it also expands access to credit and lending opportunities.

\section{Barriers to Banking in the Mainstream Market}

The economic principles of transaction costs and behavioral economics may also be barriers in preventing low-income individuals from entering the mainstream banking market. Other obstacles to using traditional banks include a general distrust of banks or unfamiliarity with traditional financial institutions and their services (Fellows and Mabanta 2008). Explaining these obstacles and their causes will help policymakers understand the mechanisms necessary to create a public policy program which effectively overcomes these deterrents and helps bank the unbanked.

\section{Transaction Costs}

The term transaction cost refers to the cost of conducting business in a market. Transaction costs are often monetary, butcan also be paid in other resources such as time, effort, and opportunity costs. Economist Ronald Coase suggests that the magnitude of transaction costs influences whether or not an individual is willing to conduct business. Coase explains that individuals can be discouraged from conducting business if the costs of the transaction outweigh the benefits (Coase 1960).

Unbanked individuals often believe that the fees, costs, and regulations associated with traditional banking overshadow any perceived benefits. For these individuals, sign-up fees, overdraft charges, and minimum balance requirements are transaction costs they are reluctant to pay. In a 2011 study of unbanked individual conducted by the Pew Health Group, 50 percent reported not having bank accounts because of their "perceived inability to deposit the minimum opening balance," and 12 percent attributed being unbanked to concerns about "hidden or expensive bank fees" (Pew Health Group 2011, 9). The Pew study also found that 14 percent of surveyed unbanked individuals avoided using traditional banks because they did not have a proper identification card, which is required by many banks to open an account (Pew Health Group 2011).

Another transaction cost for unbanked individuals is physical access to a traditional financial institution. For low-income individuals, check cashers and predatory lenders are more accessible than traditional banking institutions because they are more often located near low-income neighborhoods and operate during more convenient hours for individuals who work outside of the typical 9 a.m. to 5 p.m. schedule or who work multiple jobs (National League of Cities 2011). The inconvenience of traditional banks is a transaction cost that unbanked individuals often do not desire to pay.

\section{Lack of Financial Literacy}

Another barrier to entering the mainstream banking market for low-income individuals is a lack of information about or distrust in traditional financial institutions. According to the Federal Reserve Survey of Consumer Finances (2004), 23 percent of unbanked households reported that they do not trust banks and do not like using them (Fellows and Mabanta 2008). Low-income individuals often mistrust traditional banks either due to a lack of information about how to bank or because of previous negative experiences such as paying overdraft fees, bouncing checks, or poor credit histories (Stuhldreher 2006).

Matt Fellowes from the Brookings Institution found evidence of this sentiment when he interviewed individuals in San Francisco prior to the launch of Bank On San Francisco, a public program 
designed to bank the unbanked. Fellowes found that unbanked individuals avoid using regular banks because of the high "hidden fees," like minimum balances and overdraft fees. But, at the same time, these respondents also acknowledged that check cashers charge "excessively high fees" (Phillips and Stuhldreher, 4).

Since the cost of banking is a concern for the unbanked, these individuals could benefit from learning how much of their income they are losing to check cashers and payday lenders. Clarifying the high cost of alternative banking services may help deter low-income individuals from relying on them to meet their banking needs. Therefore, financial literacy education is a critical component in helping to bank the unbanked.

\section{Behavioral Economics}

Conventional economics states that individuals make choices to maximize personal gain or profit. The theory of behavioral economics, however, explores why individuals make decisions that do not obey conventional economic norms (Pindyck and Rubinfeld 2009). The behavioral economic theory of hyperbolic spending helps explain why unbanked individuals spend more money on alternative banking services.

Hyperbolic spending is the economic theory that individuals will prefer to save money in the future instead of in the present (Thaler and Benartzi 2004). A real-world application of this concept may provide justification for why unbanked individuals overlook the long-term financial impact of using check cashers and payday lenders. Unbanked individuals with hyperbolic spending could be well served by financial literacy education that explains the long-term financial benefits of avoiding costly check cashing and payday lending.

\section{Bank On San Francisco: A Model Program for Replication}

In 2006, then-mayor of San
Francisco Gavin Newsom introduced a program called Bank On San Francisco with the goal of decreasing the number of residents in the city who were unbanked (Stuhldreher 2006). This public-private partnership between the city, financial institutions, and nonprofit organizations expanded access to low-cost banking services, created new low-cost bank accounts and removed some costly fees, provided financial literacy education, and prevented the development of nontraditional banking services in the city (Stuhldreher 2006).

The program, still in operation today, successfully surpassed its original goal of banking 10,000 unbanked individuals in the first two years of operation (Phillips and Stuhldreher 2011). As of 2011, more than 70,000 previously unbanked residents of San Francisco had opened bank accounts through the program (Phillips and Stuhldreher 2011).

The Bank On San Francisco program is implemented in partnership with local banks and the nonprofit community. Each partner plays a specific role in implementing the program. Partner banking institutions agree to provide low-income consumers with low-cost services and extra safety nets (Stuhldreher 2006). Specifically, partner banks offer low or no-cost starter accounts with no minimum balance requirement for the low-income unbanked market, provide "second chance" accounts for individuals with poor credit histories, and waive one overdraft fee per year (FRBSF 2011). To further reduce barriers to access, banks agree to accept international identification cards from immigrant customers as a form of personal identification (FRBSF 2011).

The nonprofit community also donates its services to further the program's goals. The online organization One Economy/The Beehive, a leading web resource for low-income communities, has provided free online financial literacy education to low-income San Francisco residents (FRBSF 2011). Also, United Way 
established a partnership between Bank On San Francisco and its 2-1-1 Helplink information hotline in order to answer questions from residents about how to take advantage of Bank On San Francisco's financial tools (FRBSF 2011).

To inform San Franciscans about their eligibility for Bank On San Francisco, city agencies conducted outreach efforts to increase awareness about the program. City officials targeted low-income individuals by advertising Bank On San Francisco through the existing communication infrastructure of the Working Families Credit program (Stuhldreher 2006). City agencies and community partners also executed Bank On San Francisco launch parties across the city to distribute marketing materials about the program.

\section{Planning for Replication: Economic Costs to Consider}

If a city or state is seeking to replicate a "banking the unbanked" program similar to Bank On San Francisco, there are additional economic costs that should be considered. An examination of these economic costs will help government officials successfully replicate that program.

Redirecting Resources Away from Other Welfare Programs

Operating a program like Bank On San Francisco means that resources and attention will likely be taken away from existing government initiatives in order to fund the new program. Even though San Francisco relied heavily on its partners to execute the public-private partnership, the city also allocated staff resources to help launch the program (Stuhldreher 2006). Because cities and states function with limited funding and personnel, it is critical that these resources are utilized efficiently.

Transaction Costs Paid by Participating Banks

Participating banks in the Bank On San Francisco program were essential partners who offered low-cost starter accounts and also modified some of their fees and requirements in order to expand their services to a wider market of consumers. The banks that joined Bank On San Francisco needed to address certain factors that should also be considered by local banks that participate in future replications of the program. First, by relaxing eligibility requirements for opening an account, a bank may be exposed to a group of consumers that could exploit the program, for example, individuals with a criminal history of defaulting on loans.

Additionally, the banks participating in the Bank On San Francisco program donated their staff and services to the program. Bank employees learned about the new low-cost accounts and eligibility requirements, and then also served the additional customers attracted by the program.

\section{Negative Consequences for Consumers}

Lastly, other factors to consider are the potentially negative consequences for the unbanked consumers themselves. Specifically, for individuals that spend all of their income every pay period, dealing in cash instead of using checks or debit cards might actually be a helpful method for avoiding overspending. Using non-cash forms of payment might make the consumer more susceptible to overdrawing a checking account or bouncing a check.

\section{Federal Action on Financial Literacy}

The success of Bank On San Francisco prompted 70 cities and states across the country to create similar programs, and President Obama announced in 2010 his intentions to develop a federal Bank On USA program (Phillips and Stuhldreher 2011). The federal Bank On USA program is part of a dialogue about financial literacy that is taking place on the national political stage within the context of the recent economic 
recession and foreclosure crisis.

In January 2010, President Obama created (through Executive Order 13530) the President's Advisory Council on Financial Capability to advise his administration on strategies for increasing financial literacy and expanding access to financial products and services. In May 2012, the Council released the Money As You Grow campaign to educate youth from ages 3 to 18 about effectively managing money (Kadlec 2012).

The campaign website features age-specific financial advice coupled with targeted activities for youth. Children from ages 6 to 10 are taught that savings accounts protect money and earn interest, and are encouraged to visit a bank and to open a savings account with a parent or guardian. Individuals aged 18 years and over are encouraged to save three months of living expenses to have a financial safety net and are warned never to use a credit card unless the full balance can be paid every month. Relevant activities are suggested on the website, such as estimating monthly living expenses, searching for a credit card with a low-interest rate and no annual fees, and learning how to access free annual credit checks (President's Advisory Council on Financial Capability, n.d).

Other federal efforts to improve the financial well-being of all Americans are led by the CFPB, a new agency created by the Dodd-Frank Wall Street Reform and Consumer Protection Act of 2010. The mission of the CFPB is to "make markets for consumer financial products and services work for Americans - whether they are applying for a mortgage, choosing among credit cards, or using any number of other consumer financial products" (CFPB 2013a). As the CFPB website explains, "in a market that works, consumers should be able to make direct comparisons among products and no provider should be able to build, or feel pressure to build, a business model around unfair, deceptive, or abusive practices" (CFPB 2013a).

A priority task for the CFPB is to investigate the payday lending industry with an eye toward reform. Currently unregulated by the federal government, payday lenders will soon face a new level of accountability. CFPB Director Richard Cordray announced in January 2012 that his agency would be utilizing its new regulatory authority to conduct a comprehensive review of short-term, high-cost payday lenders throughout the country (Cordray 2012). In particular, Director Cordray remarked that the agency will be researching this industry in order to better understand the payday lending market and its impact on consumers, as well as to examine how these loans are marketed to customers (Cordray 2012). This research will contribute significantly to determining the appropriate interventions necessary to create a more transparent and competitive payday lending industry (Cordray 2012). Cordray also explained that the CFPB will examine the motivations and financial awareness of individuals who repeatedly use payday lenders to access money (Cordray 2012).

\section{Conclusion}

Banking the unbanked is a valuable opportunity to increase the financial stability of low-income individuals and families by connecting them to traditional banking services, which are more cost-effective than alternative banking services and also provide avenues for building good credit and saving more money.

In order to effectively bank the unbanked, the economic considerations of transaction costs and hyperbolic spending must be addressed in program design and legislation. Financial literacy education is an effective instrument for breaking down the misconceptions about the cost of transacting with traditional banks and discouraging hyperbolic spending. It is also critical for banks to consider eliminating minimum balances and punitive overdraft fees in order to reduce transaction costs faced by low-income consumers. 
The Bank on San Francisco program is a model for how to successfully bank the unbanked. Using San Francisco's program as a road map, state and local officials in other cities and states could implement similar programs to help lowincome individuals gain more financial stability.

\section{References}

Coase, Ronald Harry. 1960. "The Problem of Social Cost.” The Journal of Law and Economics. 3: 1-23.

CFPB (Consumer Finance Protection Bureau). 2013a. “About Us.” Accessed March 3.

- - . 2013b. "What is my credit score?" Accessed March 17, 2013. http://www. consumerfinance.gov/askcfpb/315/what-is-my-credit-score.html.

Desmond, Tyler and Charles Sprenger. 2007. "Estimating the Cost of Being Unbanked," Communities \& Banking 18(2): 26.

Cordray, Richard. 2012. "Remarks by Richard Cordray at the Payday Loan Field Hearing in Birmingham Alabama, January 19, 2012.” Accessed March 3, 2013. http:www. consumerfinance.gov/speeches/remarks-by-richard-cordray-at-the-paydayloan-field-hearing-in-birmingham-al/.

FRBSF (Federal Reserve Bank of San Francisco). 2011. "Bank On San Francisco." Accessed February 3, 2013. http://www.frbsf.org/community/issues/assets/ bankonsf/initiative_partners.html.

-_-. 2013. "Bank On San Francisco." Accessed February 3, 2013. http://www.frbsf. org/community/issues/assets/bankonsf/index.html.

Fellowes, Matt and Mia Mabanta. 2008. "Banking in Wealth: America's New Retail Banking Infrastructure and Its Wealth-Building Potential.” Metropolitan Policy Program, Brooking Institution.

Kadlec, Dan. 2012. "What President Obama Wants You to Tell Your Kids About Money And When," TIME Magazine. May 22. http://business.time.com/2012/05/22/ what-president-obama-wants-you-to-tell your-kids-about-money-and-when/.

National League of Cities. 2011. "Bank On Cities: Connecting Residents to the Financial Mainstream." Institute for Youth, Education and Families.

Phillips, Leigh and Anne Stuhldreher. 2011. "Building Better Bank Ons: Top Ten Lessons from Bank On San Francisco." New America Foundation. http://assets.newamerica.net/sites/newamerica.net/files/policydocs/ PhillipsStuhldreherBankOn2-11.pdf.

President's Advisory Council on Financial Capability. n.d. “Money As You Grow.” http:// moneyasyougrow.org.

Pew Health Group. 2011. "Slipping Behind: Low-Income Los Angeles Households Drift Further from the Financial Mainstream.” October 2011.

Pindyck, Robert S. and Daniel Rubinfeld. 2009. Microeconomics $7^{\text {th }}$ Edition: 185-186.

Stuhldreher, Anne. 2006. "Bank on San Francisco: An initiative to bring all residents into the financial mainstream." Washington, DC. http://www.frbsf.org/community/issues/assets/bankonsf/resources/casestudy.pdf.

Thaler, Richard H. and Shlomo Benartzi. 2004. "Save more tomorrow: Using behavioral economics to increase employee saving." Journal of Political Economy 112(S1): S164-S187.

Washington, Ebonya. 2006. "The impact of banking and fringe banking regulation on the number of unbanked Americans." Journal of Human Resources 41(1): 106137 . 
Emily Robbins is a Masters of Public Policy student focusing on urban policy issues at The George Washington University. She previously worked for the Boston City Council on economic development, housing, and education policies and developed an urban policy platform for a Boston mayoral candidate. Currently, she manages partnership development for The George Washington University's Graduate School of Education and Human Development.

The author would like to thank Tricia Wajda for her mentorship and for her introduction to this important policy area. Huge thanks to the editorial team (Michael Holzer, Josette Arevalo, Kristin Hubing, and Anne Berry) for your wise advice, excellent edits, and for managing countless rounds of tracked changes. A special thank you to Professor Nancy Augustine for providing guidance and support to the author both on this article and in her urban policy studies. Extreme gratitude to the author's family, friends, and Brandon for their endless supply of encouragement. 